\title{
ANALISIS TINGKAT KEPATUHAN HUKUM BERLALU LINTAS BAGI PENGEMUDI ANGKUTAN UMUM ANTAR KOTA DI MAKASAR
}

\author{
A. Aco Agus, Mustari, Firman Umar \\ Fakultas Ilmu Sosial, Universitas Negeri Makassar \\ e-mail: tenri@yahoo.com
}

\begin{abstract}
ABSTRAK
Penelitian ini bertujuan untuk mengetahui dan menjelaskan tingkat kepatuhan hukum berlalu lintas pengemudi angkutan kota/angkutan umum antar kota pada terminal bayangan di kota Makasar. Jenis penelitian ini termasuk penelitian deskriptif, dengan fokus penelitian yaitu mengkaji tingkat kepatuhan hukum pengemudi angkutan kota. Populasi dalam penelitian adalah keseluruhan bahan-bahan hukum yang terdiri dari perundang-undangan, majalah dan jurnal hukum, buku-buku hukum, serta berbagai sumber data yang memiliki karakteristik tertentu yang terkait dengan fokus dan kajian penelitian. Teknik penarikan sampel dalam penelitian ini adalah purposive sampling yakni dengan memilih bahan-bahan hukum yang membahas tentang pengemudi angkutan kota/angkutan umum antar kota pada terminal bayangan,Undang-Undang lalu lintas, buku hukum tentang kepatuhan hukum serta lalu lintas dan angkutan Jalan. Teknik pengumpulan data yaitu teknik dokumen dengan mengumpul berbagai dokumen-dokumen hukum. Teknik analisis data yang digunakan dalam penelitian ini adalah analisis deskriptif yaitu menganalisis dokumen-dokumen hukum yang terkait bidang lalu lintas dan angkutan Jalan. Hasil penelitian menunjukkan bahwa Tingkat kepatuhan hukum berlalu lintas pengemudi angkutan umum antar kota, berada pada tingkat kepatuhan hukum yang masih rendah, dengan indikator bahwa, pengemudi mengetahui bahwa kegiatan menaikkan dan menurunkan penumpang sesungguhnya adalah terminal yang sudah di tentukan oleh pemerintah daerah, bukan terminal bayangan, sebagaimana yang dilakukan oleh sebagian besar sopir angkutan umum antar kota.
\end{abstract}

Kata Kunci : Kepatuhan, Lalu Lintas, Pengemudi Angkutan Umum

\section{PENDAHULUAN}

Kepatuhan hukum dan kesadaran hukum secara sosiologi adalah keadaaan seseorang warga negara yang tunduk dan patuh dalam satu aturan (hukum) yang berlaku. Kepatuhan dan ketaatan ini didasarkan pada kesadaran-kesadaran atau nilai-nilai yang terdapat di dalam diri manusia tentang hukum yang ada maupun hukum yang diharapkan akan ada. Dengan demikian, kesadaran hukum yang dimiliki oleh warga masyarakat menjamin, bahwa warga masyarakat tersebut akan menaati suatu peraturan hukum.

Munculnya kesadaran hukum ini didorong oleh sejauh mana kepatuhan kepada hukum yang didasari oleh Indoctrination, habituation, utility dan group identification. Indoctrination merupakan sebab pertama mengapa masyarakat mematuhi kaidah-kaidah hukum. Induktrinasi adalah sebuah proses yang dilakukan berdasarkan satu sistem 
nilai untuk menanamkan sistem berpikir dan berperilaku. Habituation adalah proses penciptaan situasi dan kondisi dimana dan kapan saja membiasakan diri untuk berperilaku sesuai nilai dan telah menjadi karakter dirinya. Utility adalah nilai guna. maksudnya kegunaan/manfaat mematuhi kaidah-kaidah hukum.

Secara sosiologi kepatuhan hukum adalah keadaan seseorang warga masyarakat yang tunduk patuh dalam satu aturan (hukum) yang berlaku, dan salah satu aturan hukum yang perlu dpatuhi adalah Undang-Undang Nomor 22 tahun 2009 Tentang Lalu lintas dan angkutan jalan.

Lalu Lintas dan Angkutan Jalan mempunyai peran strategis dalam mendukung pembangunan dan integrasi nasional sebagai bagian dari upaya memajukan kesejahteraan umum sebagaimana diamanatkan oleh UndangUndang Dasar Negara Republik Indonesia Tahun 1945.

Salah satu permasalah yang mendasar dalam menerapkan hukum atau undang-undang lalu lintas dan angkutan jalan tersebut adalah permasalahan pada tingkat kepatuhan pengemudi angkutan kota/angkutan umum yang sering berhenti atau parkir sembarangan, bukan di dalam terminal angkutan kota/angkutan umum, sehingga membuat jalanan menjadi macet, selain kurangnya kepatuhan dan kesadaran dari sopir angkutan kota/angkutan umum tersebut untuk bisa tertib. Hal tersebut yang mewarnai kondisi penataan angkutan kota dan angkutan umum di Kota Makasar. Sekalipun penataan angkutan transportasi yang merupakan kendaraan umum dengan rute sudah ditentukan, halte sebagai tempat pemberhentian yang sudah ditentukan, dan bahkan terminal yang sudah disiapkan sebagai prasarana transportasi untuk keperluan memuat dan menurunkan barang, serta mengatur kedatangan dan keberangkatan kendaraan umum (angkutan umum) tersebut.

\section{TINJAUAN PUSTAKA}

\section{Hakikat Kepatuhan Hukum}

Menurut Soerjono, (1986), Salman (1989) ada 3 (tiga) beberapa faktor yang menyebabkan warga masyarakat mematuhi hukum, antara lain: a) Comliance, b) Identification, c) Internalization.

\section{a) compliance}

"an overt acceptance induced by expectation of rewards and an attempt to avoid possible punishment - not by any conviction in the desirability of the enforced nile. Power of the influencing agent is based on "means-control" and, as a consequence, the influenced person conforms only under surveillance".

Suatu kepatuhan yang didasarkan pada harapan akan suatu imbalan dan usaha untuk menghindari diri dari hukuman atau sanksi yang mungkin dikenakan apabila seseorang melanggar ketentuan hukum. Kepatuhan ini sama sekali tidak didasarkan pada suatu keyakinan pada tujuan kaidah hukum yang bersangkutan, dan lebih didasarkan pada pengendalian dari pemegang kekuasaan.. Sebagai akibatnya, kepatuhan hukum akan ada apabila ada pengawasan yang ketat terhadap pelaksanaan kaidah-kaidah hukum tersebut.

\section{b) Identification}

"an acceptance of a rule not because of its intrinsic value and appeal but because of a person's desire to maintain membership in a group or relationship with the agent. The source of power is the attractiveness of the relation which the persons enjoy with the group or agent, and his conformity with the rule will be dependent upon the salience of these relationships"

Terjadi bila kepatuhan terhadap kaidah hukum ada bukan karena nilai intrinsiknya, akan tetapi agar 
keanggotaan kelompok tetap terjaga serta ada hubungan baik dengan mereka yang diberi wewenang untuk menerapkan kaidah hukum tersebut. Daya tarik untuk patuh adalah keuntungan yang diperoleh dari hubungan-hubungan tersebut, dengan demikian kepatuhan tergantung pada baik-buruk interaksi.

\section{c) Internalization,}

"the acceptance by an individual of a rule or behavior because he finds its content intrinsically rewarding ... the content is congruent with a person's values either because his values changed and adapted to the inevitable". (Soekanto, 1986, Pospisil, 1971)

Pada tahap ini seseorang mematuhi kaidah hukum karena secara intrinsik kepatuhan tadi mempunyai imbalan. Isi kaidah tersebut adalah sesuai dengan nilai-nilainya dari pribadi yang bersangkutan, atau karena Ia mengubah nilai-nilai semula dianutnya. Hasil dari proses tersebut adalah suatu konformitas yang didasarkan pada motivasi secara intrinsik. Titik sentral dari kekuatan proses ini adalah kepercayaan orang tadi terhadap tujuan dari kaidah-kaidah yang bersangkutan, terlepas dari pengaruh atau nilainilainya terhadap kelompok atau pemegang kekuasaan maupun pengawasannya. Tahap ini merupakan derajat kepatuhan tertinggi, dimana ketaatan itu timbul karena hukum yang berlaku sesuai dengan nilai-nilai yang dianut.

\section{Hakikat Kesadaran Hukum}

Kesadaran hukum dengan hukum itu mempunyai kaitan yang erat sekali. Kesadaran hukum merupakan faktor dalam penemuan hukum. Bahkan Krabbe menyatakan bahwa sumber segala hukum adalah kesadaran hukum (Krabbe dalam Van Aveldoorn (1996). Dengan demikian maka yang disebut hukum hanyalah yang memenuhi kesadaran hukum kebanyakan orang, maka undang-undang yang tidak sesuai dengan kesadaran hukum kebanyakan orang akan kehilangan kekuatan mengikat. (Tutik, 2006).

Mertokusumo (2007) dalam buku Bunga Rampai Ilmu Hukum mengatakan: Kesadaran hukum adalah kesadaran tentang apa yang seyogyanya kita lakukan atau perbuat atau yang seyogyanya tidak kita lakukan atau perbuat terutama terhadap orang lain. Kesadaran hukum mengandung sikap toleransi (Tutik, 2006).

Kesadaran hukum merupakan cara pandang masyarakat terhadap hukum itu, apa yang seharusnya dilakukan dan tidak dilakukan terhadap hukum, serta penghormatan terhadap hak-hak orang lain (tenggang rasa). Ini berarti bahwa dalam kesadaran hukum mengandung sikap toleransi.

Dalam kenyataanya ada beberapa hal secara include perlu ditekankan dalam pengertian kesadaran hukum;

Pertama, kesadaran tentang 'apa itu hukum' berarti kesadaran bahwa hukum itu merupakan perlindungan kepentingan manusia. Karena pada prinsipnya hukum merupakan kaedah yang fungsinya untuk melindungi kepentingan manusia.

Pada hakekatnya kesadaran hukum masyarakat tidak lain merupakan pandangan-pandangan yang hidup dalam masyarakat tentang apa hukum itu. Pandangan-pandangan yang hidup di dalam masyarakat bukanlah semata-mata hanya merupakan produk pertimbanganpertimbangan menurut akal saja, akan tetapi berkembang di bawah pengaruh beberapa faktor seperti agama, ekonomi poliitik dan sebagainya Sebagai pandangan hidup didalam masyarakat maka tidak bersifat perorangan atau subjektif, akan tetapi merupakan resultante dari kesadaran hukum yang bersifat subjektif.

Kedua, kesadarn tentang 'kewajiban hukum kita terhadap orang lain' berarti dalam melaksanakan hak akan hukum kita dibatasi oleh hakmorang lain 
terhadap hukum itu. Dengan begitu dalam kesadaran hukum menganut sikap tenggang rasa/toleransi, yaitu seseorang harus menghormati dan memperhatikan kepentingan orang lain, dan terutama tidak merugikan orang lain.

Ketiga, kesadaran tentang adanya atau terjadinya 'tindak hukum' berarti bahwa tentang kesadaran hukum itu baru dipersoalkan atau dibicarakan dalam media elektronik kalau terjadi pelanggaran hokum seperti: pembunuhan, pemerkosaan, terorisme, KKN dan lain sebagainya.

Hakikat Undang-Undang Nomor 22 Tahun 2009 Tentang Lalu Lintas dan Angkutan Jalan

Undang-undang No. 22 Tahun 2009 tentang Lalu Lintas dan Angkutan Jalan yang digagas oleh Departemen Perhubungan, dibuat agar penyelenggaraan lalu lintas dan angkutan jalan sesuai harapan masyarakat, sejalan dengan kondisi dan kebutuhan penyelenggaraan lalu lintas dan angkutan jalan saat ini, serta harmoni dengan Undang-undang lainnya. Yang lebih penting dari hal tersebut adalah bagaimana kita dapat menjawab dan menjalankan amanah yang tertuang didalamnya. Sesuai dengan Pasal 7 ayat $2 \mathrm{e}$ dinyatakan: "bahwa tugas pokok dan fungsi Polri dalam hal penyelenggaraan lalu lintas sebagai suatu urusan pemerintah di bidang registrasi dan identifikasi kendaraan bermotor dan pengemudi, penegakkan hukum, operasional manajemen dan rekayasa lalu lintas, serta pendidikan berlalu lintas".

Dengan menyadari pentingnya peranan transportasi, maka lalu lintas dan angkutan jalan harus ditata dalam suatu sistem transportasi nasional secara terpadu dan mampu mewujudkan tersedianya jasa transportasi yang sesuai dengan tingkat kebutuhan lalu lintas dan pelayanan angkutan yang tertib, nyaman, cepat, teratur, lancar dan dengan biaya yang terjangkau oleh daya beli masyarakat.
Untuk itu pemerintah telah mengeluarkan kebijakan di bidang transportasi darat yaitu dengan dikeluarkannya UU No. 22 Tahun 2009 tentang Lalu Lintas dan Angkutan Jalan sebagai Pengganti UU No. 14 Tahun 1992, serta Peraturan Pemerintah No. 41 Tahun 1993 tentang Angkutan Jalan yang masih tetap berlaku meskipun PP No. 41 Tahun 1993 merupakan peraturan pelaksanaan dari UU No. 14 tahun 2003 dikarenakan disebutkan dalam Pasal 324 UU No. 22 Tahun 2009 bahwa : "Pada saat Undang-Undang ini mulai berlaku, semua peraturan pelaksanaan Undang-Undang Nomor 14 Tahun 1992 tentang Lalu Lintas dan Angkutan Jalan (Lembaran Negara Republik Indonesia Tahun 1992 Nomor 49, Tambahan Lembaran Negara Republik Indonesia Nomor 3480) dinyatakan tetap berlaku sepanjang tidak bertentangan atau belum diganti dengan yang baru berdasarkan Undang-Undang ini ".

Dalam pasal 2 dan pasal 3 UndangUndang Lalu Lintas dan Angkutan Jalan (yang selanjutnya disingkat dengan UULLAJ) mengatur asas dan tujuan pengangkutan. Adapun Asas penyelenggaraan lalu lintas adalah diatur dalam Pasal 2 UULLAJ yakni :

Lalu Lintas dan Angkutan Jalan diselenggarakan dengan memperhatikan: a) asas transparan, b) asas akuntabel, c) asas berkelanjutan, d) asas partisipatif, e) asas bermanfaat, f) asas efisien dan efektif, g) asas seimbang, h) asas terpadu dan i) asas mandiri.

Sedangkan Pasal 3 UULAJ menyebutkan mengenai tujuan dari Lalu Lintas dan Angkutan Jalan yakni:

a. Terwujudnya pelayanan Lalu Lintas dan Angkutan Jalan yang aman, selamat, tertib, lancar, dan terpadu dengan moda angkutan lain untuk mendorong perekonomian nasional, memajukan kesejahteraan umum, memperkukuh persatuan dan kesatuan bangsa, serta mampu menjunjung tinggi martabat bangsa;

b. Terwujudnya etika berlalu lintas dan budaya bangsa; 
c. Terwujudnya penegakan hukum dan kepastian hukum bagi masyarakat.

Dengan berlakunya UU No. 22 Tahun 2009 tersebut diharapkan dapat membantu mewujudkan kepastian hukum bagi pihak-pihak yang terkait dengan penyelenggaraan jasa angkutan, baik itu pengusaha angkutan, pekerja (sopir/ pengemudi) serta penumpang. Secara operasional kegiatan penyelenggaraan pengangkutan dilakukan oleh pengemudi atau sopir angkutan dimana pengemudi merupakan pihak yang mengikatkan diri untuk menjalankan kegiatan pengangkutan atas perintah pengusaha angkutan atau pengangkut. Pengemudi dalam menjalankan tugasnya mempunyai tanggung jawab untk dapat melaksanakan kewajibannya yaitu mengangkut penumpang sampai pada tempat tujuan yang telah disepakati dengan selamat, artinya dalam proses pemindahan tersebut dari satu tempat ke tempat tujuan dapat berlangsung tanpa hambatan dan penumpang dalam keadaan sehat, tidak mengalami bahaya, luka, sakit maupun meninggal dunia. Sehingga tujuan pengangkutan dapat terlaksana dengan lancar dan sesuai dengan nilai guna masyarakat.

\section{METODE PENELITIAN}

Jenis penelitian ini termasuk penelitian deskriptif, dengan fokus penelitian yaitu mengkaji tingkat kepatuhan hukum pengemudi angkutan kota, serta analisis terhadap substansi Undang-Undang Nomor 22 Tahun 2009 tentang lalu lintas dan angkutan jalan, khususnya pada pasal 3 tentang pelayanan yang aman dan tertib, dan pasal 36 tentang pemamfaatan terminal. Adapun Jenis dan sumber data dalam penelitian ini adalah:

1. Data primer yaitu data yang diperoleh dari responden (pengemudi angkutan kota) dengan menggunakan teknik wawancara (interview) dan Observasi (pengamatan). Data ini digunakan dalam rangka pemenuhan data mengenai subjek penelitian.

2. Data sekunder yaitu data yang diperoleh melalui hasil penelusuran dan penelaah studi kepustakaan yaitu buku-buku atau referensi yang relevan dengan kajian ini.

Untuk mendapatkan data yang lengkap dan valid dalam penelitian ini, maka digunakan teknik pengumpulan data yang sesuai dengan keadaan dan sifat penelitian yaitu metode wawancara kepada para pengemudi angkutan umum antar kota.Teknik analisis data yang digunakan dalam penelitian ini adalah analisis deskriptif, yaitu menganalisis hasil wawancara serta dokumen-dokumen hukum yang terkait dengan kepatuhan hukum pengemudi angkutan umum antar kota.

\section{HASIL DAN PEMBAHASAN}

\section{Tingkat Kepatuhan Hukum Berlalu Lintas Pengemudi AngkutanUmum Antar Kota di Kota Makassar}

Kepatuhan hukum terkait dengan kesadaran hukum, setiap manusia normal mempuyai kesadaran hukum. Masalahnya ada pada taraf kesadaran hukum, yakni tinggi, sedang, dan rendah. Tolok ukur taraf-taraf kesadaran adalah (1) pengetahuan mengenai hukum, (2) pemahaman terhadap hukum, (3) sikap terhadap hukum, dan (4) perilaku hukum. Seseorang yang dianggap mempunyai kesadaran hukum yang tinggi apabila perilakunya sesuai dengan ketentuanketentuan hukum yang berlaku. Dengan demikian, maka taraf kesadaran hukum yang tinggi didasarkan pada kepatuhan hukum, akan tetapi tidak setiap yang mematuhi hukum mempunyai kesadaran hukum. 
Terjadinya kepatuhan hukum dapat disebabkan oleh hal-hal: (1) takut kena sanksi, (2) memelihara hubungan baik dengan pengusaha, memelihara hubungan baik dengan rekan-rekan dalam kelompok, terjaminnya kepentingan pribadi, (5) aturan hukum sesuai dengan nilai-nilai yang dianut.

Pengemudi angkutan umum antar kota dalam beraktivitas tidak luput dari ketentuan-ketentuan hukum yang seharusnya dipatuhi. UndangUndang Nomor 22 Tahun 2009 tentang Lalu Lintas dan Angkutan Jalan antara lain dimaksudkan agar terwujud kepastian hukum dalam penyelenggaraan jasa angkutan, baik pengusaha angkutan, pekerja (pengemudi, kernek) serta penumpang, sehingga terlaksana ketertiban, keamanan, dan kenyamanan dalam pemanfaatan jasa angkutan umum dan dalam berlalulintas.

Kota Makassar sebagai kota yang menjadi tujuan utama dari arus lintas angkutan antar kota di Sulawesi Selatan, menjadikan mobil angkutan umum antar kota memadati jalan-jalan di Kota Makassar untuk mengantar maupun menjemput penumpang dari dan ke kota/daerah lain. Agar terwujud kelancaran dan ketertiban di jalan dalam kota maka semua pengguna jalan mematuhi peraturan-peraturan Undang-Undang Lalu Lintas dan Angkutan Jalan dan peraturanperaturan lain yang terkait, antara lain peraturan daerah yang menyangkut lalu lintas dan angkutan jalan.

Hasil wawancara terhadap informan (sopir) mobil angkutan antar kota yang mangkal di depan markas AURI Daya, biasa para sopir dan penumpang menyebutnya dengan "terminal bayangan" bahwa semua sopir (10 informan) menjawab mereka memiliki SIM, STNK, dan perlengkapan kendaraan.

Menurut Fadli, 35 tahun, sopir Trayek Makassar - Sengkang, bahwa: "SIM, STNK, dan perlengkapan kendaraan (dongrak, ban serep, alatalat standar lainnya) semua lengkap. Cuma STNK-nya sering tidak sesuai dengan plat (plat gantung), ... tidak ada izin trayek... pakai mobil plat hitam (mobil pribadi)... ada sebagian pakai plat kuning yang biasa masuk terminal sekedar lewat cari penumpang, kecuali bus-bus besar mungkin semua plat kuning. ...pokoknya bisa bawa penunumpang..."

Para sopir mengaku kalau dalam menekuni profesi sopir mobil penumpang antar kota pasti ada aturanaturanya dari pemerintah, mereka tidak tahu apa nama peraturannya tersebut. Hal ini disampaikan oleh Anto, 33 tahun, sopir Makassar - Sengkang, bahwa: "...ada aturan tapi tidak tahu nama aturannya, tahu tidak boleh mangkal di luar terminal, tahu tidak boleh pakai plat hitam, tahu harus ada izin trayek, KIR... tapi biar tidak ada tetap bisa beroperasi..."

Hal yang sama disampaikan oleh Zainal, 35 tahun, sopir trayek Makassar - Polman, bahwa: “... kalau ada operasi/sweeping selalu disampaikan patuhi peraturan, lengkapi surat-surat kendaraan, tapi tidak disampaikan apa nama peraturannya, ...biasa polisi, petugas Dishub/DLLAJR, ... mengetahui kalau harus pakai plat mobil umum/kuning, ambil penumpang seharusnya di terminal, tapi di terminal kurang penumpang, juga di dalam banyak pungutan yang memberatkan, umumnya mobil yang beroperasi mobil pribadi, sama halnya mobil-mobil 
rental. ... jarang ditilang, ujungujungnya jalan 'damai'.'

Onding, 39 tahun, trayek Makassar - Pinrang, menyatakan bahwa: ...masalah peraturan angkutan antar kota kami lupa nama peraturannya, tapi pokoknya kami memiliki surat-surat lengkap, hanya izin trayek dulu pernah diurus pihak kantor (pemilik angkutan), kalau sekarang pakai plat hitam supaya mudah menjemput dan mengantar penumpang kapan dan di mana saja alamatnya. ...seperti mobil rental tanggung sopir."

Faktor-faktor yang Mempengaruhi Tingkat Kepatuhan Hukum Berlalu Lintas Pengemudi Angkutan Umum Antar Kota di Kota Makassar

Terjadinya kepatuhan hukum dapat disebabkan oleh hal-hal: (1) takut kena sanksi, (2) memelihara hubungan baik dengan pengusaha, (3) memelihara hubungan baik dengan rekan-rekan dalam kelompok, (4) terjaminnya kepentingan pribadi, (5) aturan hukum sesuai dengan nilai-nilai yang dianut.

Berdasarkan hasil wawancara terhadap informandapat diidentifikasi faktor-faktor yang mempengaruhi tingkat kepatuhan hukum berlalu lintas pengemudi angkutan umum antar kota di Kota Makassar, adalah (1) faktor internal meliputi pengetahuan dan pemahaman para sopir yang rendah tentang ketentuan-ketentuan hukum, kurangnya kesadaran para sopir yang untuk mematuhi hukum yang berlaku, (2) faktor eksternal meliputi memadainya sosialisasi mengenai ketentuan-ketentuan hukum berlalu lintas dan angkutan jalan, perilaku penumpang yang mencari penumpang di luar terminal dan minta dijemput di alamat masing-masing, serta penegakan hukum oleh aparat (kepolisian, dinas perhubungan) tidak tegas.

\section{Tanggapan Pengemudi Angkutan Umum Antar Kota Terhadap Ketentuan Undang-Undang Nomor 22 Tahun 2009 tentang Lalu Lintas dan Angkutan Jalan di Kota Makassar.}

Undang-Undang Nomor 22 tahun 2009 tentang lalu lintas dan angkutan jalan pasal 1 menyatakan bahwa Lalu Lintas dan Angkutan Jalan adalah suatu kesatuan sistem yang terdiri atas lalu lintas, angkutan jalan, jaringan lalu lintas dan angkutan jalan, prasarana lalu lintas dan angkutan jalan, kendaraan, pengemudi, pengguna jalan, serta pengelolaannya.

Semua informan yang dimintai tanggapannya mengenai ketentuan Undang-Undang Nomor 22 Tahun 2009 tentang Lalu Lintas dan Angkutan Jalan, menjawab mereka menjawab tidak tahu-menahu tentang hal-hal apa saja yang diatur. Para informan mengetahui kalau persoalan berlalu lintas dan angkutan umum antar kota ada aturannya, seperti harus punya SIM, STNK, Izin Trayek, dan kelengkapan lainnya, termasuk terminal tempat menaikkan dan menurunkan penumpang, mobil pakai plat kuning (umum), serta larangan menunggu dan menurunkan penumpang di sembarang tempat. Namun, para sopir tidak mengetahui apa nama undang-undang atau peraturan yang mengaturnya.

\section{Pembahasan}

Tingkat kepatuhan hukum pengemudi angkutan di terminal daya 
makassar, akan dianalisis dengan menggunakan tiga indikator tentang kepatuhan seseorang dalam mematuhi hukum, sebagaimana tampak dalam analisis sebagai berikut:

\section{Compliance}

Pada tingkat kepatuhan hukum ini adalah paling rendah. Kepatuhan hukum seseorang hanya pada perilaku luarnya saja, sementara dalam dirinya sebenarnya ia punya pendapat berbeda dari apa yang dilakukannya. Kepatuhan hukum hanya ada pada perilaku (behavior) tetapi tidak pada sikap (attitude).

Pada tingkatan compliance kepatuhan hukum seseorang dilandasi rasa takut akan terkena sanksi. Kepatuhan hukum bertujuan agar ia terhindar dari sanksi hukum. Hukum dalam konteks compliance lebih bermakna kepada petugas hukum. Seseorang mematuhi hukum karena ada petugas hukum yang mengawasi perbuatannya dan oleh karena itu ia mematuhi hukum. Pada tingkat kepatuhan ini, pengemudi angkutan kota di terminal daya Makassar yang disebut terminal bayangan, tidak dalam kategori takut sanksi, karena para sopir angkutan sesungguhnya mengetahui bahwa terminal sesungguhnya adalah yang sudah ditentukan oleh pemerintah daerah, akan tetapi karena faktor petugas yang tidak tegas dalam melakukan penertiban, sehingga para sopir dengan leluasa untuk melakukan aktivitas diterminal bayangan tersebut.

\section{Internalization}

Pada tahap ini seseorang mematuhi kaidah hukum karena secara intrinsik kepatuhan tadi mempunyai imbalan. Isi kaidah tersebut adalah sesuai dengan nilai-nilainya dari pribadi yang bersangkutan, atau karena Ia mengubah nilai-nilai semula dianutnya. Hasil dari proses tersebut adalah suatu konformitas yang didasarkan pada motivasi secara intrinsik. Titik sentral dari kekuatan proses ini adalah kepercayaan orang tadi terhadap tujuan dari kaidah-kaidah yang bersangkutan, terlepas dari pengaruh atau nilai-nilainya terhadap kelompok atau pemegang kekuasaan maupun pengawasannya. Tahap ini merupakan derajat kepatuhan tertinggi, dimana ketaatan itu timbul karena hukum yang berlaku sesuai dengan nilai-nilai yang dianut. Para sopir angkutan kota di terminal bayangan daya Makassar beranggapan bahwa apa mereka lakukan adalah salah, akan tetapi karena kondisi penumpang pada terminal yang sesungguhnya itu adalah sepi penumpang, serta kurang tegasnya aparat LLAJR, sehingga mereka tetap mencari penumpang pada terminal bayangan tersebut. Oleh karena itu peneliti beranggapan bahwa para sopir tersebut mereka memiliki nilai-nilai kesadaran dan nilai kepatuhan hukum, hanya saja mereka terpengaruh dengan kondisi atau keadaan yang ada.

\section{Identification}

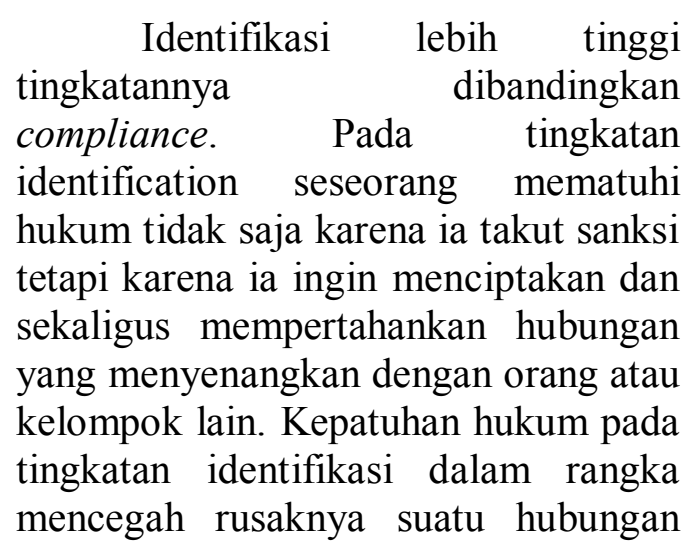


baik yang telah terbentuk atau menghindari lahirnya hubungan yang tidak baik seseorang dengan pihak lain.

Pada tingkat kepatuhan hukum ini, tidak nampak pada pengemudi angkutan kota di terminal bayangan daya Makassar karena sesungguhnya para sopir tersebut merasa nyaman untuk melakukan aktifitas mencari penumpang, sekalipun hal tersebut adalah bagian dari pelanggaran UULAJR.

Selanjutnya faktor yang mempengaruhi tingkat kepatuhan para sopir angkutan umum antar kota adalah pengetahuan dan pemahaman terhadap UULAJR. Disamping itu juga adalah faktor kurangnya sosialisasi dari aparat LLAJR tentang UULAJR. Serta ketidaktegasan aparat dalam memberi tindakan atau sanksi, Sehingga para sopir beranggapan bahwa mereka melakukan aktivitas mencari /menaikkan menumpang dan menurunkan penumpang adalah sahsah saja.

Para sopir angkutan beranggapan bahwa, jika mereka memiliki kelengkapan surat-surat kendaran serta memiliki surat izin mengemudi, dianggap sebagai sesuatu yang bisa dengan leluasa melakukan aktivitas mencari penumpang, dan dianggap mematuhi aturan UULLAJR. Oleh karena itu peneliti beranggapan bahwa para sopir angkutan belum memiliki pengetahuan baik terhadap UULAJR.

\section{KESIMPULAN}

Berdasarkan pembahasan hasil peneliitian, maka dapat dikemukakan kesimpulan sebagai berikut:

1. Tingkat kepatuhan hukum berlalulintas pengemudi angkutan umum antar kota, berada pada tingkat kepatuhan hukum yang masih rendah, dengan indikator bahwa, pengemudi mengetahui bahwa kegiatan menaikkan dan menurunkan penumpang sesungguhnya adalah terminal yang sudah di tentukan oleh pemerintah daerah, bukan terminal bayangan, sebagaimana yang dilakukan oleh sebagian besar sopir angkutan umum antar kota.

2. Faktor yang mempengaruhi tingkat kepatuhan para sopir angkutan umum antar kota di terminal bayangan daya kota Makassar adalah faktor kurangnya sosialisasi UULAJR dan ketidaktegasan aparat penegak hukum dalam memberikan sanksi, serta faktor kesadaran masyarakat sendiri atau penumpang.

3. Tanggapan pengemudi angkutan umum antar kota di terminal bayangan daya kota Makassar terhadap ketentuan UULAJR. masih sangat terbatas sebagian besar beranggapan bahwa jika kelengkapan surat-surat kendaraan sudah ada maka dianggap sudah mematuhi ketentuan UULAJR.

\section{DAFTAR PUSTAKA}

Mertokusumo, Sudikno 2007, Mengenal hukum suatu pengantar, ed.ke3 cet.ke-1. Yogyakarta: Liberty.

Peraturan Pemerintah No. 41 Tahun 1993 tentang Angkutan Jalan

Pospisil L., Anthropology of Law, A Comparative Theory, Harper \& Row Publisher, London, 1971.

Salman, Otje. (1989). Beberapa Aspek Sosiologi Hukum. Bandung: Alumni

Soekanto, Soerjono. 1986. Pengantar Penelitian Hukum. UI Press, Jakarta. 
Tutik, Titik Triwulan. 2006. Pengantar Ilmu Hukum. Surabaya : PT. Prestasi Pustaka.

Van aveldoorn. 1996. Pengantar Ilmu Hukum. Jakarta : PT.Pradanya Paramita.

Undang-Undang Nomor 14 Tahun 1992 tentang Lalu Lintas dan Angkutan Jalan

Undang-Undang Nomor 22 Tahun 2009 tentang Lalu lintas dan Angkutan Jalan

Undang-Undang Nomor 14 Tahun 2003 tentang Perhitungan Anggaran Negara Tahun Anggaran 2001 